\title{
KESESUAIAN TEKNIS DAN OPERASIONAL PANGKALAN PENDARATAN IKAN DONGGALA DENGAN PERMEN-KP RI NOMOR PER.08/MEN/2012 TENTANG KEPELABUHANAN PERIKANAN
}

\author{
Technical and Operational Congeniality of Donggala Fish Landing with PERMEN-KP RI \\ NUMBER PER.08/MEN/2012 Concerning Fisheries Ports
}

\author{
Oleh: \\ Aksa Azhari Aminullah", Mulyono S. Baskoro², Mohammad Imron³, Iin Solihin ${ }^{4}$ \\ ${ }^{1}$ Departemen Pemanfaatan Sumberdaya Perikanan, Fakultas Perikanan dan Ilmu Kelautan, Institut Pertanian Bogor, Bogor. \\ aksaazhari9@gmail.com \\ 2Departemen Pemanfaatan Sumberdaya Perikanan, Fakultas Perikanan dan Ilmu Kelautan, Institut Pertanian Bogor, Bogor. \\ baskoro.mul@gmail.com \\ ${ }^{3}$ Departemen Pemanfaatan Sumberdaya Perikanan, Fakultas Perikanan dan Ilmu Kelautan, Institut Pertanian Bogor, Bogor. \\ mohammad.imron@gmail.com \\ ${ }^{4}$ Departemen Pemanfaatan Sumberdaya Perikanan, Fakultas Perikanan dan Ilmu Kelautan, Institut Pertanian Bogor, Bogor. \\ Iin_solihin@apps.ipb.ac.id \\ * Korespondensi: aksaazhari9@gmail.com
}

\begin{abstract}
Donggala fish landing centre is a fishery infrastructure of Donggala Regency provided for Mamuju Regency fishermen, West Sulawesi. Capture fisheries activities in PPI Donggala are incorporating various stages from landing to marketing. All capture fisheries activities are related to the PPI Donggala's technical and operational condition. Some of purse seine fishing units did not land their catches at PPI Donggala which affect the performance of the fishing port. This study aims to identify the PPI Donggala's technical and operational condition in compliance with PERMEN-KP RI NUMBER PER.08/MEN/2012 concerning Fisheries Ports. The research method is a case study conducted at PPI Donggala. Data were collected by interviews and literature studies, then analyzed using comparative descriptive method. The results of the study showed the technical and operational conformity of the port at PPI Donggala with PERMEN KP 08/2012 on Fisheries Port has met technical and operational criteria. However, there are still technical and operational constraints in PPI Donggala. The obstacle is that the pier is still damaged and the marketing of the catch has not been widespread.
\end{abstract}

Keywords: PPI Donggala, technical aspects, operational aspects

\section{ABSTRAK}

Pangkalan Pendaratan Ikan Donggala merupakan prasarana perikanan bagi nelayan Kabupaten Donggala hingga Kabupaten Mamuju, Sulawesi Barat. Aktivitas perikanan tangkap yang ada di PPI Donggala mulai dari kegiatan pendaratan hasil tangkapan hingga pemasaran hasil tangkapan. Seluruh aktivitas perikanan tangkap yang ada di PPI Donggala berkaitan dengan teknis dan operasional kepelabuhanan. Sebagian besar unit penangkapan ikan purse seine tidak melakukan pendaratan hasil tangkapan di PPI Donggala yang dapat berdampak pada kinerja pelabuhan. Penelitian ini bertujuan untuk mengidentifikasi teknis dan operasional PPI Donggala serta kesesuaian dengan PERMEN-KP RI NOMOR PER.08/MEN/2012 tentang Kepelabuhanan 
Perikanan. Metode penelitian yang digunakan adalah studi kasus pada teknis dan operasional PPI Donggala. Wawancara dan studi literatur dilakukan terhadap responden kemudian dianalisis secara deskriptif komparatif. Hasil penelitian menunjukkan kesesuaian teknis dan operasional kepelabuhanan di PPI Donggala dengan PERMEN KP 08/2012 tentang Kepelabuhanan Perikanan sudah memenuhi kriteria tersebut, kriteria teknis dan kriteria operasional. Namun, masih terdapat kendala pada teknis dan operasional kepelabuhanan di PPI Donggala. Kendala tersebut yaitu dermaga yang masih mengalami kerusakan dan pemasaran hasil tangkapan belum meluas.

Kata kunci: PPI Donggala, aspek teknis, aspek operasional.

\section{PENDAHULUAN}

Kabupaten Donggala yang berada di Provinsi Sulawesi Tengah memiliki potensi perikanan tangkap yang cukup besar. Hal tersebut dibuktikan dengan produksi perikanan tangkap Kabupaten Donggala sejak tahun 2016 sampai 2020 berturut-turut sebesar $22.998,50$ ton, $24.520,90$ ton, $18.022,7$ ton, 20.759, 9 ton, dan 15.414, 2 ton (DKP Provinsi Sulawesi Tengah 2020). Besarnya produksi tersebut dipengaruhi oleh wilayah Kabupaten Donggala yang memiliki panjang pesisir pantai $414 \mathrm{~km}$ dengan 15 pulau kecil yang berada di sekitarnya dan berada di sebelah barat berbatasan langsung dengan Selat Makassar (Rukka 2016). Potensi inilah yang menjadi alasan Provinsi Sulawesi Tengah melalui Dinas Kelautan dan Perikanan Sulawesi Tengah membangun prasarana Pangkalan Pendaratan Ikan (PPI).

Pangkalan Pendaratan Ikan (PPI) Donggala merupakan prasarana perikanan bagi nelayan Kabupaten Donggala hingga Kabupaten Mamuju, Sulawesi Barat. Fasilitas yang ada di PPI Donggala yaitu fasilitas dermaga, kolam pelabuhan, perbaikan jaring, pabrik es, air bersih, tempat pelelangan ikan higienis (TPIH), Stasiun Pengisian Bahan Bakar Nelayan (SPBN). Pengelola PPI Donggala melakukan pembinaan kelompok usaha bersama (KUB) nelayan, teknis dan mutu hasil perikanan, serta pembinaan pengawasan sumberdaya ikan. Fasilitas yang tersedia serta kegiatan yang difasilitasi oleh pengelola PPI Donggala memudahkan nelayan dalam melakukan aktivitas perikanan tangkap.

Aktivitas perikanan tangkap yang ada di PPI Donggala dimulai dari kegiatan pendaratan hasil tangkapan $(\mathrm{HT})$ hingga pemasaran hasil tangkapan. Aktivitas perikanan tangkap yang utama di pelabuhan perikanan meliputi empat aktivitas, yaitu: (1) Aktivitas pendaratan hasil tangkapan (2) Aktivitas penyediaan kebutuhan melaut (3) Aktivitas pemasaran dan
(4) Aktivitas pengolahan (Hutapea et al. 2017; Santoso et al. 2018; Suherman et al. 2020). Seluruh aktivitas perikanan tangkap yang ada di PPI Donggala berkaitan dengan teknis dan operasional kepelabuhanan.

Teknis kepelabuhan adalah ketersediaan fasilitas dalam pelaksanaan fungsi dan peranannya pada pelabuhan tersebut (Setiawan et al. 2019). Operasional kepelabuhanan adalah fungsionalisasi pelabuhan terhadap fasilitas yang ada (Ngamel et al. 2014). Teknis dan operasional kepelabuhan yang ada di PPI Donggala didukung oleh adanya unit penangkapan ikan yang melakukan aktivitas perikanan tangkap. Jenis unit penangkapan ikan yang terdapat pada PPI Donggala hanya ada dua jenis, yaitu purse seine dan hand line. Purse seine merupakan alat tangkap yang menyumbang kontribusi hasil tangkapan terbesar di PPI Donggala. Berdasarkan data laporan tahunan PPI Donggala tahun 2016 sampai 2019 menunjukkan bahwa hasil tangkapan purse seine sejumlah 1107 ton, 1898 ton, 2249 ton, dan 3038 ton. Namun, sebagian besar dari unit penangkapan ikan purse seine Donggala yang telah melakukan operasi penangkapan ikan tidak melakukan pendaratan hasil tangkapan di PPI Donggala. Hal ini dapat berdampak pada penurunan pendapatan retribusi dan penjualan perbekalan melaut di pelabuhan. Penyebab dari nelayan tidak mau mendaratkan hasil tangkapan belum diketahui, dimana aktivitas pendaratan hasil tangkapan merupakan bagian dari teknis dan operasional kepelabuhanan PPI Donggala. Oleh sebab itu, diperlukan identifikasi terkait teknis dan operasional sebagai dasar untuk mengetahui keterkaitan tidak dilakukannya pendaratan hasil tangkapan unit penangkapan ikan purse seine di PPI Donggala. Selanjutnya dilakukan analisis kesesuaian teknis dan operasional PPI Donggala dengan PERMEN-KP RI NOMOR PER.08/MEN/2012 tentang Kepelabuhanan Perikanan. Hal ini digunakan untuk mengetahui apakah PPI Donggala sudah atau belum memenuhi standar PERMEN tersebut. Pene- 
litian ini diharapkan menjadi informasi dasar pengelolaan teknis dan operasional bagi pengelola PPI Donggala.

\section{METODE}

Pengumpulan data dilakukan di PPI Donggala. Pengumpulan data dilakukan pada bulan Desember 2019-Januari 2020. Penelitian ini dilaksanakan berdasarkan studi kasus terkait kesesuaian teknis dan operasional PPI Donggala dengan PERMEN-KP RI NOMOR PER.08/MEN/2012 tentang Kepelabuhanan Perikanan. Jenis data yang digunakan dalam penelitian ini dikumpulkan melalui wawancara dan studi literatur. Adapun jenis dan pengumpulan data untuk mencapai tujuan dari penelitian ini, dapat dilihat pada Tabel 1.

Pengumpulan data identifikasi teknis dan operasional PPI Donggala diperoleh melalui wawancara menggunakan kuesioner dan studi literatur. Wawancara dilakukan dengan nahkoda kapal purse seine dan pihak pengelola PPI Donggala. Penentuan responden yang diwawancara adalah dengan menggunakan metode purposive sampling, sampel responden ditentukan berdasarkan pertimbangan penelitian (Mboto et al. 2014; Nurhayati et al. 2019). Terkait pengambilan responden nahkoda kapal purse seine menggunakan teknik accidental sampling. Accidental sampling adalah prosedur sampling yang memilih sampel dari orang atau unit yang mudah ditemui atau kebetulan ditemukan (Mahardhika et al. 2018; Muninggar et al. 2020) pada populasi subyek penelitian. Jumlah populasi unit penangkapan purse seine di PPI Donggala berjumlah 76 unit. Responden yang diambil sebanyak 19 unit penangkapan mengacu pada Pinello et al. (2017) yang menyatakan bahwa penentuan sampel dari populasi kapal ikan jika berjumlah 50-500 unit maka diambil sampel sebanyak $25 \%$. Responden pihak pengelola PPI Donggala yaitu Kepala Unit Pelaksana Teknis Pelabuhan Perikanan Wilayah 1 PPI Donggala, satu orang Syahbandar PPI Donggala, dan satu orang Pengawas Perikanan PPI Donggala. Setelah data diperoleh, kemudian dikomparasikan dengan PERMEN-KP RI NOMOR PER.08/MEN/2012 tentang Kepelabuhanan Perikanan untuk melihat kesesuaian dari teknis dan operasional PPI Donggala.

Data identifikasi kesesuaian teknis dan operasional PPI Donggala dengan PERMEN-KP RI NOMOR PER.08/MEN/2012 tentang Kepelabuhan Perikanan dianalisis secara deskriptif komparatif. Analisis ini bertujuan menyajikan informasi kondisi operasional di PPI Donggala yang kemudian dibandingan dengan PERMEN-KP tersebut. Aspek yang diidentifikasi yaitu terkait fasilitas dan aktivitas kepelabuhan di PPI Donggala. Hasil wawancara menggunakan kuesioner dan studi literatur mengenai fasilitas dan aktivitas yang ada di PPI Donggala dideskripsikan untuk mengetahui kondisi operasional di PPI Donggala. Selanjutnya dilakukan perbandingan dengan PERMEN-KP RI NOMOR PER.08/MEN/2012 tentang Kepelabuhan Perikanan. Kriteria pada PERMEN-KP tersebut terdiri atas dua, yaitu kriteria teknis dan operasional pelabuhan perikanan. Kriteria-kriteria tersebut memiliki indikator (Tabel 2) yang tertera pada PERMENKP RI NOMOR PER.08/MEN/2012 tentang Kepelabuhan Perikanan. Hasil tersebut kemudian dibandingkan dengan kondisi eksisting berdasarkan pengamatan di lapangan. Kesesuaian kondisi PPI Donggala dengan kriteria dan indikator dilihat dari terpenuhinya kriteria dan indikator dengan kondisi eksisting.

Tabel 1 Jenis dan Pengumpulan Data

\begin{tabular}{|c|c|c|c|c|c|}
\hline No & Tujuan & Data & $\begin{array}{c}\text { Pengumpulan } \\
\text { Data }\end{array}$ & $\begin{array}{c}\text { Sumber } \\
\text { data }\end{array}$ & Analisis data \\
\hline 1. & $\begin{array}{l}\text { Mengidentifikasi } \\
\text { kesesuaian teknis dan } \\
\text { operasional } \\
\text { PPI Donggala dengan } \\
\text { PERMEN-KP RI } \\
\text { NOMOR } \\
\text { PER.08/MEN/2012 } \\
\text { tentang Kepelabuhanan } \\
\text { Perikanan }\end{array}$ & $\begin{array}{l}\text { Fasilitas dan aktivitas } \\
\text { kepelabuhanan } \\
\text { di PPI Donggala }\end{array}$ & $\begin{array}{l}\text { Wawancara } \\
\text { menggunakan } \\
\text { kuesioner dan studi } \\
\text { literatur }\end{array}$ & $\begin{array}{l}\text { Nahkoda } \\
\text { kapal purse } \\
\text { seine, KUPT } \\
\text { Pelabuhan } \\
\text { Perikanan } \\
\text { Wilayah } 1 \text { PPI } \\
\text { Donggala, } \\
\text { satu orang } \\
\text { Syahbandar } \\
\text { PPI } \\
\text { Donggala, } \\
\text { satu orang } \\
\text { Pengawas } \\
\text { perikanan PPI } \\
\text { Donggala. }\end{array}$ & $\begin{array}{l}\text { Analisis } \\
\text { deskriptif } \\
\text { komparatif }\end{array}$ \\
\hline
\end{tabular}


Tabel 2 Kriteria-kriteria PERMEN-KP RI NOMOR PER.08/MEN/2012 tentang Kepelabuhan Perikanan

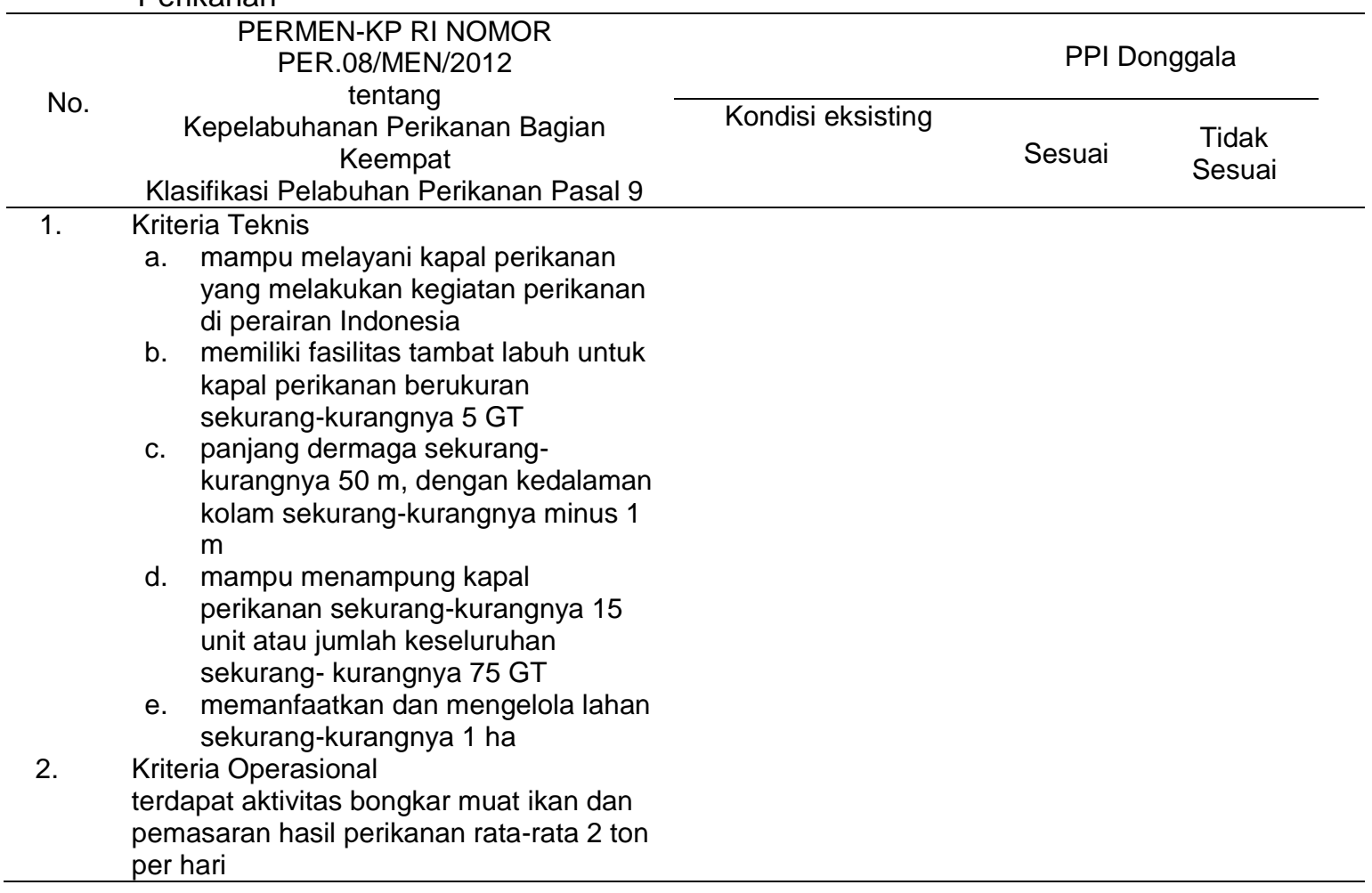

HASIL

\section{Kesesuaian Teknis dan Operasional PPI Donggala dengan PERMEN-KP RI NOMOR PER.08/MEN/2012 tentang Kepelabuhanan Perikanan}

Hasil identifikasi teknis dan operasional PPI Donggala terkait kesesuaian dengan PERMEN KP no. 08 tahun 2012 tentang Kepelabuhanan Perikanan serta kesesuaian dengan kondisi eksisting terlihat pada Tabel 3.

Data hasil kesesuaian teknis dan operasional PPI Donggala dengan PERMENKP RI NOMOR PER.08/MEN/2012 tentang Kepelabuhanan Perikanan pada (Tabel 3), berdasarkan hasil pengamatan dan wawancara terhadap indikator kesesuaian, menunjukkan PPI Donggala memiliki kesesuaian teknis dan operasional mencapai 100\%.

Berdasarkan kriteria teknis, yaitu variabel mampu melayani kapal perikanan yang melakukan kegiatan perikanan di Perairan Indonesia sesuai dengan kondisi pelayanan yang ada di PPI Donggala. Hasil pengamatan terkait pelayanan unit penangkapan ikan di PPI Donggala, menunjukkan bahwa pengelola PPI Donggala mampu melayani nelayan dalam pengurusan administrasi penerbitan SLO dan SPB. Pihak pengelola PPI Donggala mampu mengeluarkan SPB dan SLO 5 sampai 10 kapal tiap harinya, tergantung dari jumlah kapal yang akan berangkat melaut. Walaupun dalam PERMEN-KP RI NOMOR PER.08/MEN/2012 tentang Kepelabuhanan Perikanan tidak menyebutkan standar nilai indikator jumlah kapal, akan tetapi dengan adanya data jumlah kapal memperkuat hasil analisis bahwa pelayanan unit penangkapan di PPI Donggala sudah sesuai.

Unit penangkapan purse seine yang berpangkalan di PPI Donggala hanya berjumlah 76 kapal dengan kisaran gross tonnage (GT) 10 sampai 30 (PPI Donggala 2019). Unit penangkapan purse seine yang ada di PPI Donggala memiliki kisaran panjang 10-20 m, lebar 2-4 m, dan tinggi 1-1,5 m. Unit penangkapan purse seine Donggala mayoritas nelayannya merupakan penduduk asli Kabupaten Donggala. Unit penangkapan purse seine di PPI Donggala status kepemilikannya dikelola secara berkelompok (KUB) maupun perorangan (PPI Donggala 2019), dan biasanya operasi penangkapan ikan dilakukan di sekitar perairan Selat Makassar.

Variabel memiliki fasilitas tambat labuh untuk kapal perikanan berukuran sekurangkurangnya 5 GT sudah sesuai dengan kondisi 
yang ada di PPI Donggala. Berdasarkan hasil pengamatan, fasilitas tambat labuh yang ada di PPI Donggala tersedia untuk kapal ikan dengan kapasitas mulai dari 5 sampai 30 GT. Kapal ikan yang bertambat dan berlabuh yaitu purse seine.

Variabel panjang dermaga sekurangkurangnya $50 \mathrm{~m}$, dengan kedalaman kolam sekurang-kurangnya minus $1 \mathrm{~m}$ sudah sesuai dengan kondisi yang ada di PPI Donggala. Fasilitas dermaga yang ada di PPI Donggala saat ini memiliki ukuran panjang $120 \mathrm{~m}$ dengan kedalaman kolam pelabuhan saat air pasang mencapai $7 \mathrm{~m}$, saat air surut menjadi $2 \mathrm{~m}$ (Gambar 2). Dermaga kapal purse seine $80 \mathrm{~m}$ dan dermaga kapal hand line $40 \mathrm{~m}$ yang sekaligus dijadikan docking kapal perikanan yang ada di PPI Donggala. Gempa dan tsunami yang pernah terjadi tahun 2018 silam, mengakibatkan kerusakan pada dermaga tambat labuh kapal purse seine sepanjang 20 meter dan dermaga lain untuk docking sepanjang 10 meter.

Variabel mampu menampung kapal perikanan sekurang-kurangnya 15 unit atau jumlah keseluruhan sekurang-kurangnya 75 GT sudah sesuai dengan daya tampung di PPI Donggala. Kolam pelabuhan yang ada di PPI Donggala memiliki luas $1800 \mathrm{~m} 2$ dengan kedalaman $2 \mathrm{~m}$ (Gambar 3). Berdasarkan hasil wawancara dan pengamatan, jumlah unit penangkapan ikan purse seine yang menggunakan kolam pelabuhan sebanyak 20 unit. Meskipun kapasitasnya melebihi kriteria yang ada, namun kolam pelabuhan tersebut mayoritas digunakan perahu kecil saat bongkar muat hasil tangkapan kapal lain.

Saat air laut pasang tertinggi, kedalaman kolam menjadi $7 \mathrm{~m}$ dan pada saat surut menjadi $2 \mathrm{~m}$. Saat terjadinya air pasang tertinggi, kapal-kapal purse seine bisa memasuki kolam pelabuhan jika di dermaga utama penuh. Sering terjadinya pendangkalan pada kolam pelabuhan, maka kapal-kapal ikan yang ada di PPI Donggala mayoritas memilih bertambat pada dermaga di luar dari kolam pelabuhan.

Variabel memanfaatkan dan mengelola lahan sekurang-kurangnya 1 ha lahan/lokasi, sudah sesuai dengan kondisi yang ada di PPI Donggala. Pada tahun 2006 lahan/lokasi hanya seluas $20.000 \mathrm{~m} 2$ dan pengalami perluasan lahan/lokasi pada tahun 2015 seluas $10.000 \mathrm{~m} 2$. Sehingga saat ini lahan/lokasi PPI Donggala menjadi $30.000 \mathrm{~m} 2$ atau 3 ha (PPI Donggala tahun 2019).

Berdasarkan kriteria operasional, yaitu terdapat aktivitas bongkar muat ikan dan pemasaran hasil perikanan rata-rata 2 ton per hari, sudah sesuai dengan kondisi yang ada di PPI Donggala. Aktivitas bongkar muat ikan yang ada di PPI Donggala waktunya tidak menentu, tergantung kedatangan kapal. Aktivitas pendaratan hasil tangkapan purse seine bisa dilakukan 1-4 unit kapal secara bersamaan saat bersandar di dermaga PPI Donggala. Saat melakukan pendaratan hasil tangkapan, kuli angkut mulai berdatangan ke masing-masing kapal.

Berdasarakan hasil wawancara dengan 19 nahkoda kapal purse seine Donggala, diperoleh informasi bahwa mereka masih mengalami kendala saat melakukan aktivitas perikanan tangkap khususnya pendaratan hasil tangkapan di PPI Donggala. Kendalakendala tersebut berkaitan dengan fasilitas dan pelayanan yang ada di PPI Donggala yang diantaranya ketersediaan perbekalan melaut khususnya BBM Solar, harga hasil tangkapan ikan tidak stabil, dan fasilitas pelabuhan berupa dermaga tambat labuh masih rusak. Aktivitas bongkar muat kapal perikanan di PPI Donggala tahun 2019 sebanyak 160 kapal dengan rata-rata sebanyak 4 kapal per hari dan produksi ikan sebesar 4794 ton dengan rata-rata 13 ton per hari (PPI Donggala tahun 2019). Terkait pemasaran hasil perikanan yang ada di PPI Donggala hanya berpusat di sekitaran Kab. Donggala dan Kota Palu. 

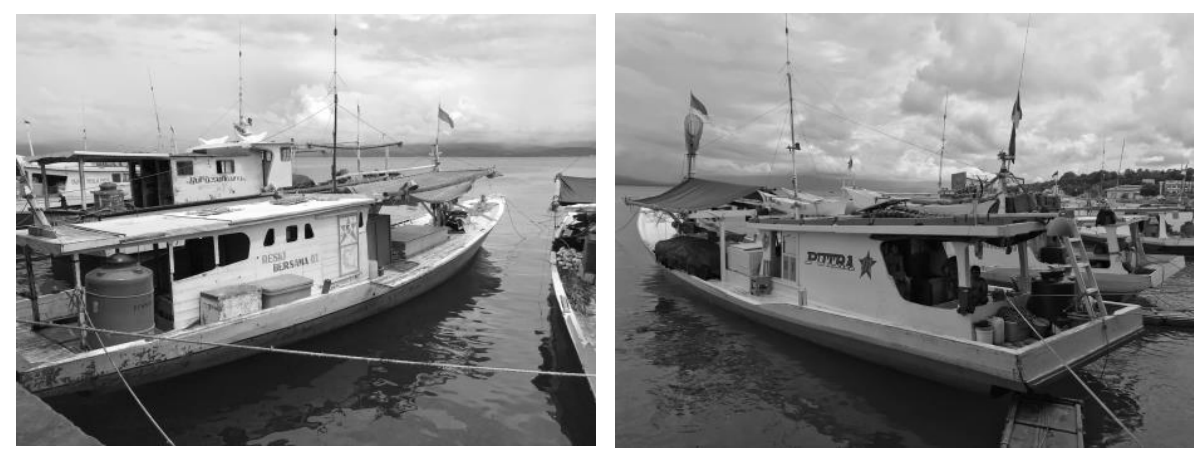

Gambar 1 Unit penangkapan ikan purse seine

Tabel 3 Kesesuaian teknis dan operasional PPI Donggala terhadap PERMEN-KP RI NOMOR PER.08/MEN/2012 tentang Kepelabuhanan Perikanan

\title{
PERMEN KP 08/2012
}

Kepelabuhanan Perikanan

PPI Donggala

No. Bagian Keempat

Klasifikasi Pelabuhan Kondisi

Sesuai Tidak

1. Kriteria Teknis

a. mampu melayani kapal pelayanan terkait

perikanan yang

melakukan kegiatan

perikanan di perairan

Indonesia fasilitas

tambat labuh

penerbitan SPB dan

SLO hanya selama

satu hari kerja saja,

dengan tujuan

penangkapan ikan di

WPP 713

b. memiliki fasilitas tambat

labuh untuk kapal

perikanan berukuran

sekurang-kurangnya 5

GT

tambat labuh sudah

tersedia, digunakan

oleh kapal purse seine

berukuran 10 sampai

30 GT

c. panjang dermaga

sekurang-kurangnya 50

panjang dermaga

hanya tersedia $80 \mathrm{~m}$

$\mathrm{m}$, dengan kedalaman

kolam sekurang-

kurangnya minus $1 \mathrm{~m}$

d. mampu menampung

kapal perikanan

sekurang-kurangnya 15

unit atau jumlah

ksisting

Sesuai

keseluruhan sekurang-

kurangnya $75 \mathrm{GT}$

e. memanfaatkan dan

mengelola lahan

sekurang-kurangnya 1

ha

kapal yang bertambat

dan berlabuh sebanyak

20 unit dengan luas kolam

$1.800 \mathrm{~m} 2$

\author{
lahan PPI Donggala \\ saat ini $30.000 \mathrm{~m} 2$ \\ atau 3 ha (PPI \\ Donggala tahun 2019
}

2. Kriteria Operasional

a. terdapat aktivitas bongkar muat ikan dan pemasaran hasil perikanan rata-rata 2 ton per hari

produksi ikan yang ada di PPI Donggala tahun 2019 sebesar 4.794 ton dengan rata-rata 13 ton per hari 

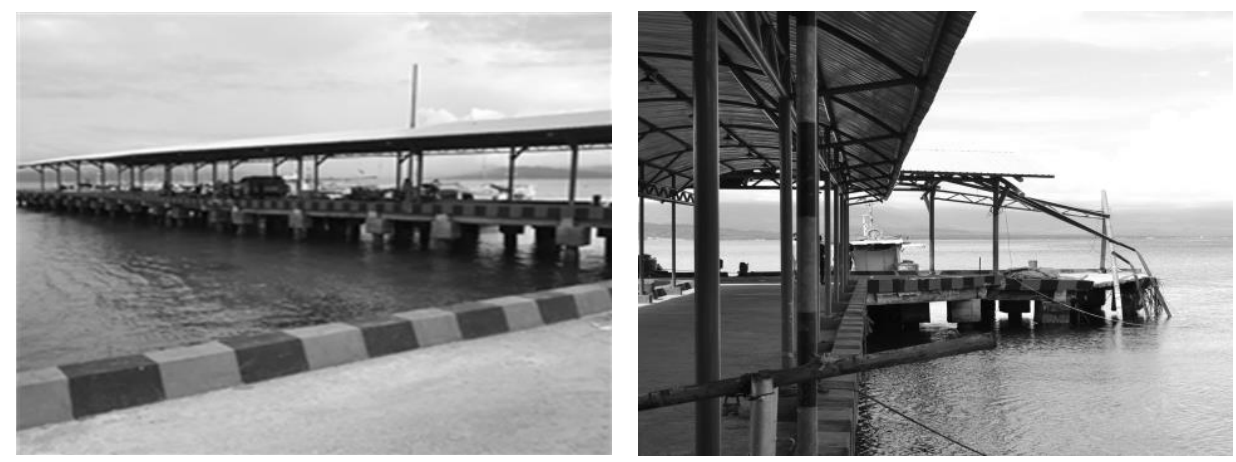

Gambar 2 Dermaga tambat labuh unit penangkapan purse seine Donggala
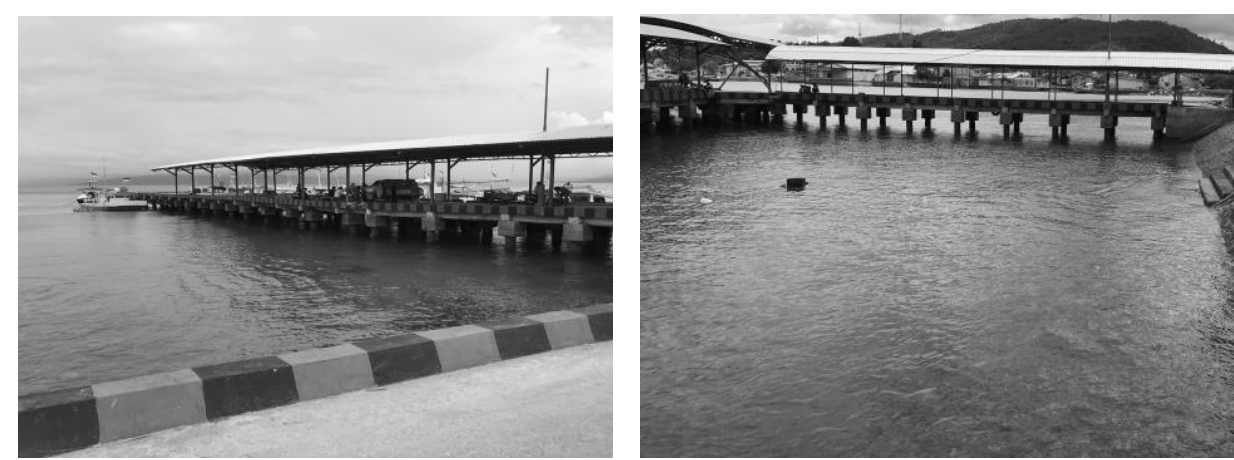

Gambar 3 Kolam pelabuhan di PPI Donggala

\section{PEMBAHASAN}

\section{Kesesuaian Teknis dan Operasional Kepelabuhanan di PPI Donggala dengan PERMEN-KP RI NOMOR PER.08/MEN/2012 tentang Kepelabuhanan Perikanan}

Teknis dan Operasional Kepelabuhanan di PPI Donggala yaitu terkait fasilitas pelabuhan serta aktivitas yang ada di pelabuhan tersebut. Teknis kepelabuhan dan operasional kepelabuhanan yang diamati di PPI Donggala merujuk pada PERMEN-KP RI NOMOR PER.08/MEN/2012 tentang Kepelabuhanan Perikanan, dimana tercantum kriteria-kriteria (Tabel 2) serta pengamatan di lokasi secara langsung. Teknis kepelabuhan adalah ketersediaan fasilitas dalam pelaksanaan fungsi dan peranannya pada pelabuhan tersebut (Setiawan et al. 2019). Operasional kepelabuhanan adalah fungsionalisasi pelabuhan terhadap fasilitas yang ada (Ngamel et al. 2014). Kriteria teknis kepelabuhanan yang teridentifikasi di PPI Donggala antara lain yaitu pelayanan unit penangkapan ikan, dermaga tambat labuh, kolam pelabuhan, Sedangkan kriteria operasional kepelabuhan yang teridentifikasi di PPI Donggala yaitu aktivitas pendaratan HT.

Penelitian Tahir et al. (2020) pada Tabel 4 menjelaskan bahwa fasilitas pokok dan fungsional di PPI Torobulu yang menjadi bagian dari kriteria teknis kepelabuhan. Kriteria yang diamati yaitu dermaga, kolam pelabuhan, gedung tempat pelelangan ikan (TPI), kebutuhan bahan bakar minyak, kebutuhan air bersih, dan kebutuhan es. Namun terdapat fasilitas yang belum termanfaatkan sepenuhnya sesuai kapasitas yang tersedia (kolam pelabuhan, gedung tempat pelelangan ikan, SPDN/ketersediaan BBM). Terdapat fasilitas yang belum tersedia/rusak (instalasi air bersih, pabrik es) atau ada fasilitas yang tingkat pemanfaatannya telah melebihi kapasitas maksimum (dermaga). Penelitian (Asrayanti et al. 2018) juga mengamati terkait fasilitas pokok, fungsional dan pendukung PPI Maccini Baji yang menjadi bagian dari kriteria teknis kepelabuhanan. Kriteria yang diamati yaitu dermaga, kolam pelabuhan, gedung pelelangan ikan, SPBN, dan Pabrik Es. Fasilitas yang ada juga mengalami kendala. Fasilitas kolam labuh tidak bisa berfungsi optimal dan membutuhkan pengerukan, sementara untuk fasilitas dermaga saat ini masih berupa revetment dan perlu dilakukan pembangunan dermaga. Pabrik Es dan SPDN juga masih memerlukan penambahan stok untuk menyuplai kebutuhan di sekitar PPI. Penelitian (Merdekawati et al. 2019) di PPI Lonrae hanya mengamati fasilitas pokok saja yang termasuk dalam kriteria teknis 
kepelabuhanan. Kriteria yang diamati yaitu dermaga, kolam pelabuhan, kedalaman perairan, dan daratan pelabuhan. Fasilitasfasilitas tersebut mengalami kendala sehingga perlu dilakukan penambahan panjang dermaga, dan pengembangan kolam pelabuhan.

Perbedaan kriteria yang teramati bisa terjadi karena tergantung dari kondisi pelabuhan tersebut. Kondisi pada pelabuhan terlihat dari teknis dan operasional kepelabuhan yang ada. Kondisi teknis kepelabuhanan yang ada di PPI Donggala tidak jauh berbeda dengan kondisi pada PPI Torobulu, PPI Maccini Baji, dan PPI Lonrae. Kondisi teknis kepelabuhanan yang ada di PPI Donggala menjadi penyebab terjadinya kendala bagi aktivitas perikanan tangkap oleh nelayan purse seine Donggala. Kendala tersebut terjadi akibat dari fasiltas dermaga tambat labuh yang masih mengalami kerusakan, dan kondisi operasional kepelabuhanan yaitu masih terdapat aktivitas bongkar muat ikan di tempat lain. Aktivitas bongkar muat ikan yang menjadi bagian operasional PPI Donggala, dimana unit penangkapan purse seine Donggala yang telah melakukan operasi penangkapan ikan di Selat Makassar tidak langsung kembali ke PPI Donggala. Kapal-kapal tersebut melakukan pendaratan HT di tempat lain, mengisi perbekalan untuk kembali melakukan operasi penangkapan. Baru akan kembali ke PPI Donggala jika sudah tidak melakukan operasi penangkapan ikan lagi. Aktivitas ini menjadi peluang pendapatan bagi tempat lain yang menyediakan perbekalan melaut, sehingga PPI Donggala kehilangan peluang memperoleh pendapatan dari retribusi dan penjualan perbekalan melaut untuk unit penangkapan purse seine. Kondisi teknis dan operasional kepelabuhanan yang ada di PPI Donggala saling terkait. Kondisi teknis kepelabuhanan yang masih belum memadai menjadi pengaruh bagi operasional kepelabuhanan di PPI Donggala. Pihak pengelola PPI Donggala harus segera menangani terkait kondisi teknis dan operasional tersebut. Jika terus dibiarkan akan makin mempengaruhi pendapatan retribusi dan penjualan perbekalan melaut di PPI Donggala. Oleh sebab itu, fasilitas yang tersedia pada pelabuhan perikanan harus dapat memenuhi kebutuhan nelayan, dimulai dari fasilitas pendaratan hingga fasilitas penunjang lainnya (Tahir et al. 2020). Adanya fasilitas di pelabuhan perikanan berperan sangat penting bagi kelangsungan aktivitas pada pelabuhan tersebut (Rosalia et al. 2019). Tersedianya fasilitas pelabuhan perikanan menjadi salah satu faktor pendukung keberhasilan operasional pelabuhan (Irham et al. 2020).

Perbandingan teknis dan operasional yang ada di PPI Donggala dengan kriteria teknis dan operasional pada PERMEN-KP RI NOMOR PER.08/MEN/2012 tentang Kepelabuhanan Perikanan sudah sesuai. Namun, masih terdapat kendala pada teknis dan operasional kepelabuhanan yang ada di PPI Donggala. Kendala teknis tersebut yaitu dermaga yang masih mengalami kerusakan serta kendala operasional yaitu pemasaran hasil tangkapan belum meluas. Penelitian (Basri et al. 2020) menunjukkan bahwa kondisi PPI Pasarwajo sudah memenuhi syarat pada PERMEN-KP RI NOMOR PER.08/MEN/2012 tentang Kepelabuhanan Perikanan namun untuk kriteria operasional tidak terpenuhi. Pada penelitian (Salim et al. 2018) kondisi fisik PPI Beba masih baik dan layak pakai sehingga memenuhi syarat pada PERMEN-KP RI NOMOR PER.08/MEN/2012 tentang Kepelabuhanan Perikanan. Dua hasil penelitian tersebut menunjukkan bahwa kondisi PPI Donggala sama dengan kondisi PPI Beba lebih memenuhi syarat kriteria dibandingkan PPI Pasarwajo. Walaupun kondisi teknis dan operasional yang ada di PPI Donggala sudah memenuhi kriteria yang ada, namun pihak pengelola PPI Dongga harus segera memperbaiki kondisi teknis yang nantinya bisa meningkatkan operasional PPI Donggala. Jika hal tersebut dibiarkan akan berdampak pada status kelas pelabuhan PPI Donggala. Menurut Pujiastuti et al. (2018), operasional suatu pelabuhan perikanan dipengaruhi oleh fasilitas yang tersedia di pelabuhan perikanan tersebut. Fasilitas pelabuhan perikanan terdiri dari fasilitas pokok, fasilitas fungsional, dan fasilitas penunjang. Fasilitas - fasilitas tersebut dibangun agar kegiatan operasional dan fungsi pelabuhan berjalan dengan baik dan optimal. Fasilitas sangat berperan dalam menunjang aktivitas di pelabuhan perikanan, berkembangnya aktivitas di pelabuhan perikanan harus diimbangi dengan pengembangan jenis dan kapasitas fasilitasnya (Lubis et al. 2011). 
Tabel 4 Perbandingan identifikasi teknis dan operasional kepelabuhanan

\begin{tabular}{|c|c|c|c|}
\hline No. & Nama Pelabuhan perikanan & Teknis Kepelabuhanan & Operasional Kepelabuhanan \\
\hline 1. & PPI Donggala & $\begin{array}{l}\text { Pelayanan unit } \\
\text { penangkapan ikan, } \\
\text { Dermaga tambat labuh, } \\
\text { Kolam pelabuhan, Lahan } \\
\text { PPI Donggala }\end{array}$ & Aktivitas bongkar muat ikan \\
\hline 2. & PPI Torobulu & $\begin{array}{l}\text { Dermaga, Kolam } \\
\text { pelabuhan, Gedung } \\
\text { tempat pelelangan ikan } \\
\text { (TPI), Kebutuhan bahan } \\
\text { bakar minyak, Kebutuhan } \\
\text { air bersih, dan kebutuhan } \\
\text { es }\end{array}$ & \\
\hline 3. & PPI Maccini Baji & $\begin{array}{l}\text { Dermaga, Kolam } \\
\text { pelabuhan, Gedung } \\
\text { pelelangan ikan, SPBN, } \\
\text { dan Pabrik Es }\end{array}$ & \\
\hline 4. & PPI Lonrae & $\begin{array}{l}\text { Dermaga, Kolam } \\
\text { pelabuhan, Kedalaman } \\
\text { perairan, dan Daratan } \\
\text { pelabuhan }\end{array}$ & \\
\hline
\end{tabular}

\section{KESIMPULAN}

Kesesuaian teknis dan operasional kepelabuhanan di PPI Donggala dengan PERMEN KP 08/2012 tentang Kepelabuhanan Perikanan sudah memenuhi kriteria teknis dan kriteria operasional. Kriteria teknis yaitu PPI Donggala mampu melayani kapal perikanan yang melakukan kegiatan perikanan di Perairan Indonesia dengan mengeluarkan SLO dan SPB untuk kapal ikan Donggala setiap harinya. Fasilitas tambat labuh di PPI Donggala tersedia untuk kapal dengan kapasitas 130 GT, kolam PPI Donggala mampu menampung unit penangkapan ikan sebanyak 20 unit, lahan/lokasi yang dikelola PPI Donggala seluas 30.000 m2 atau 3 ha, dan untuk kriteria operasional yaitu PPI Donggala mampu memproduksi dan memasarkan HT sebanyak 13 ton/hari. Namun, masih terdapat kendala pada teknis dan operasional kepelabuhanan di PPI Donggala. Kendala tersebut yaitu dermaga yang masih mengalami kerusakan dan pemasaran hasil tangkapan belum meluas.

\section{SARAN}

Saran untuk pihak pengelola PPI Donggala yaitu perbaikan fasilitas yang rusak dan perlu dilakukan penelitian lanjutan terkait tingkat kepuasan nelayan terhadap fasilitas serta pelayanan pelabuhan perikanan.

\section{UCAPAN TERIMA KASIH}

Penulis mengucapkan terimakasih kepada instansi PPI Donggala yang telah mengizinkan membantu proses penelitian.

\section{DAFTAR PUSTAKA}

Asrayanti, Danial, Ihsan. 2018. Analisis Pengelolaan Pangkalan Pendaratan Ikan (PPI) Maccini Baji Kabupaten Pangkajene dan Kepulauan. Journal of Indonesian Tropical Fisheries. 1(1): 77$88 . \quad$ https://doi.org/10.33096/jointfish.v1i1.23

Basri LOM, Tadjuddah M, Alimina N. 2020. Analisis Pemanfaatan Fasilitas Pangkalan Pendaratan Ikan (PPI) Pasarwajo Kabupaten Buton Sulawesi Tenggara. Jurnal Sains dan Inovasi Perikanan. $\quad 4(2)$ : 83-94. https://doi.org/10.33772/jsipi.v4i2.12378

[DKP] Dinas Kelautan dan Perikanan Provinsi Sulawesi Tengah. 2020. Statistik Perikanan Tangkap. DKP Provinsi Sulawesi Tengah 
Hutapea RYF, Solihin I, Nurani TW. 2017. Peran Pelabuhan Perikanan Samudera Nizam Zachman dalam Mendukung Industri Tuna. Marine Fisheries. 8(2): 187-198.

https://doi.org/10.29244/jmf.8.2.187-198

Irham, Iksan KH, Hardin. 2020. Evaluasi Fasilitas Fungsional Pelabuhan Perikanan Pantai Bacan. Jurnal IImu Kelautan Kepulauan. 3(2): 238-248. https://doi.org/10.33387/jikk.v3i2.2590

[KKP] Kementerian Kelautan dan Perikanan Republik Indonesia. 2012. Peraturan Menteri KP Nomor 8 Tahun 2012 Tentang Kepelabuhan Perikanan [Internet]. [diunduh 20 Januari 2021]. Tersedia

pada: http://infohukum.kkp.go.id

Lubis E, Mardiana N. 2011. Peranan Fasilitas PPI terhadap Kelancaran Aktivitas Pendaratan Ikan di Cituis Tangerang. Jurnal Teknologi Perikanan dan Kelautan. $\quad 1(2)$ : 1-10. https://doi.org/10.24319/itpk.2.1-10

Mahardhika SM, Saputra SW, Ain C. 2018. Valuasi Ekonomi Sumberdaya Ikan dan Ekowisata Mangrove di Muara Angke, Jakarta. Journal of Maquares. 7(4): 458464.

https://doi.org/10.14710/mari.v7i4.22670

Mboto NK, Nurawi TW, Wisudo SH, Mustaruddin. 2014. Strategi Sistem Penanganan Ikan Tuna Segar yang Baik di Kapal Nelayan hand line PPI Donggala. Jurnal Teknologi Perikanan dan Kelautan. 5(2): 191-206. https://doi.org/10.24319/jtpk.5.189-204

Merdekawati AEP, Mallawa A, Amir F. 2019. Analisis Tingkat Pemanfaatan Fasilitas Pokok di Pangkalan Pendaratan Ikan Lonrae Kabupaten Bone, Sulawesi Selatan. Jurnal IPTEKS PSP. 6(12): 165174.

https://doi.org/10.20956/ijpsp.v6i12.7382

Muninggar R, Lubis, Iskandar BH. 2020. Penilaian Parameter Ecofishingport pada Pelabuhan Perikanan Samudera Nizam Zachman Jakarta. Jurnal Teknologi Perikanan dan Kelautan. 11(1): 111-123. https://doi.org/10.24319/itpk.11.111-123

Ngamel YA, Lubis E, Pane AB, Sholihin I. 2013. Kinerja Operasional Pelabuhan
Perikanan Nusantara Tual. Jurnal Teknologi Perikanan dan Kelautan. 4(2): 155-172.

https://doi.org/10.24319/itpk.4.155-172

Nurhayati D, Atika D. 2019. Analisis Kinerja Operasional Pelabuhan Perikanan Pantai (PPP) Eretan, Indramayu. Barakuda. $\quad 1(1):$ 33-45. https://doi.org/10.47685/barakuda45.v1i $\underline{1.18}$

Pinello D, Gee J, Dimech M. 2017. Handbook for Fisheries Socio-Economic Sample Survey-Principles and Practice. Rome (IT): FAO.

Pujiastuti D, Irnawati R, Rahmawati A. 2018. Kondisi dan Tingkat Pemanfaatan Fasilitas Pangkalan Pendaratan Ikan Kronjo Kabupaten Tangerang Provinsi Banten. Jurnal Perikanan dan Kelautan. 8(1): 40-55. https://doi.org/10.33512/jpk.v8i1.3683

[PPI] Pangkalan Pendaratan Ikan Donggala. 2019. Laporan Tahunan. PPI Donggala

Rosalia AA, Pane AB, Solihin I, Hutapea RYF, Putri AS, Tirtana D. 2019. Strategi Pengembangan Pangkalan Pendaratan Ikan Cisolok, Kabupaten Sukabumi: Pendekatan Analisis SWOT. Jurnal Teknologi Perikanan dan Kelautan. 10(2): $\quad$ 191-204. https://doi.org/10.24319/itpk.10.191-204

Rukka AH. 2016. Desain Pemanfaatan Sumberdaya Ikan Layang di Perairan Kabupaten Donggala Sulawesi Tengah [disertasi]. Bogor: Institut Pertanian Bogor.

Salim A, Danial, Ihsan. 2018. Optimalisasi Pemanfaatan Pangkalan Pendaratan Ikan (PPI) Beba Galesong Utara Kabupaten Takalar Sulawesi Selatan. Journal of Indonesian Tropical Fisheries. 1(1): 40-48. https://doi.org/10.33096/joint-fish.v1i1.19

Santoso H, Asia, Hamel S, Mahonas J, Arifi MZ. 2018. Strategi Pengembangan Pelabuhan Perikanan Dagho. Jurnal Frontiers. 1(3): 283-294. https://doi.org/10.36412/frontiers/001035 e1/desember201801.06

Setiawan H, Pane AB, Lubis E. 2019. Strategi Pengembangan Pelabuhan Perikanan 
Pantai Bajomulyo untuk Meningkatkan Fungsi Pelabuhan Perikanan. Albacore. 3(1): 059-072. https://doi.org/10.29244/core.3.1.59-72

Suherman A, Boesono $H$, Kurohman $F$, Muzakir AK. 2020. Kinerja Pelabuhan Perikanan Nusantara Karangantu Banten, Indonesia. Jurnal IImu-IImu Perairan, Pesisir dan Perikanan. 9(2):
344-355.

https://doi.org/10.13170/depik.9.2.17457

Tahir M, Alimina N, Haya LOMY. 2020. Analisis Tingkat Pemanfaatan Fasilitas Pokok dan Fungsional Pangkalan Pendaratan Ikan Torobulu, Kabupaten Konawe Selatan. Jurnal Sain dan Inovasi Perikanan. 4(2): 63-73. https://doi.org/10.33772/jsipi.v4i2.13488 